\title{
Innate and adaptive $T$ cells in influenza disease
}

Simone Nüssing ${ }^{1 *}$, Sneha Sant ${ }^{1 *}$, Marios Koutsakos ${ }^{1 *}$, Kanta Subbarao ${ }^{1,2}$, Thi H.O. Nguyen ${ }^{1 \#}$ and Katherine Kedzierska ${ }^{1 \#}$

${ }^{1}$ Department of Microbiology and Immunology, University of Melbourne, at the Peter Doherty Institute for Infection and Immunity, Parkville 3010, Victoria, Australia; ${ }^{2}$ World Health Organisation (WHO) Collaborating Centre for Reference and Research on Influenza, at The Peter Doherty Institute for Infection and Immunity, Melbourne 3000, Victoria, Australia.

*These authors contributed equally.

\# These authors contributed equally.

Corresponding authors: kkedz@unimelb.edu.au (K.K.); thonguyen@unimelb.edu.au (T.H.O.N.).

Key words: Influenza, innate $\mathrm{T}$ cells, $\mathrm{CD} 4^{+}$and $\mathrm{CD}^{+} \mathrm{T}$ cells, vaccination 


\begin{abstract}
Influenza is a major global health problem, causing infections of the respiratory tract, often leading to acute pneumonia, life-threatening complications and even deaths. Over the last seven decades, vaccination strategies have been utilized to protect people from complications of influenza, especially groups at high risk of severe disease. While current vaccination regimens elicit strain-specific antibody responses, they fail to generate cross-protection against seasonal, pandemic and avian viruses. Moreover, vaccines designed to generate influenza-specific T-cell responses are yet to be optimized. During natural infection, viral replication is initially controlled by innate immunity before adaptive immune responses (T-cells and antibodyproducing B-cells) achieve viral clearance and host recovery. Adaptive T- and B-cells maintain immunological memory and provide protection against subsequent infections with related influenza viruses. Recent studies also shed light on the role of innate T-cells (MAIT cells, $\gamma \delta$ T-cells and NKT cells) in controlling influenza and linking innate and adaptive immune mechanisms, thus making them attractive targets for vaccination strategies. We summarize the current knowledge on influenza-specific innate MAIT and $\gamma \delta$ T-cells as well as adaptive CD8 ${ }^{+}$ and $\mathrm{CD}^{+}{ }^{+} \mathrm{T}$-cells, and discuss how these responses can be harnessed by novel vaccine strategies to elicit cross-protective immunity against different influenza strains and subtypes.
\end{abstract}




\section{INTRODUCTION}

Influenza viruses, are enveloped negative-sense RNA viruses with segmented genomes from the family Orthomyxoviridae that cause a highly contagious and rapidly spreading acute respiratory infection (reviewed in [1]). Annual seasonal influenza epidemics result in significant morbidity and mortality, especially amongst high-risk groups, including children, the elderly, pregnant women, obese individuals, those with co-morbidities and Indigenous populations. Sporadically, a new influenza virus emerges from an animal host and spreads rapidly in the susceptible population, resulting in a pandemic often associated with significant morbidity and mortality. Influenza viruses replicate in the respiratory mucosa, primarily in respiratory epithelial cells producing large amounts of progeny virions, which then infect alveolar macrophages and resident dendritic cells.

Three types of influenza viruses classified as A, B and C, infect humans [1,2]. While influenza A and B viruses (IAV and IBV, respectively) co-circulate annually during seasonal epidemics, influenza $\mathrm{C}$ viruses generally cause mild infections in humans. Of the three, only IAV have established animal reservoirs [2,3], although IBV have been isolated from some animal species $[4,5]$. Importantly, some swine and avian IAV strains can infect humans. Thus, seasonal IAV/IBV infections present a significant global health problem causing up to 500,000 excess deaths annually due to influenza infection [6,7]. IAVs are further distinguished into subtypes by their surface glycoproteins hemagglutinin $(\mathrm{H})$ and neuraminidase $(\mathrm{N})$ with $18 \mathrm{HA}$ subtypes and 11 NA subtypes identified to date. On the other hand, IBVs are grouped into two antigenically and genetically distinct lineages, called B/Yamagata and B/Victoria [4,5]. Two IAV subtypes (H1N1 and H3N2), along with one or two IBV viruses from the two lineages cocirculate annually causing influenza epidemics. Under immune pressure, influenza viruses acquire mutations in their HA and NA proteins, which allow immune escape in a process known as antigenic drift. Novel IAVs emerge by reassortment, mostly in animal reservoirs, in a process known as antigenic shift. Whenlif they acquire the ability to spread from person-toperson, novel IAVs can cause a pandemic $[2,3]$.

The first leukocytes that infiltrate the lungs following influenza virus infection are innate cells that include neutrophils and macrophages [8]. They are followed by influenzaspecific $\mathrm{B}$ and $\mathrm{T}$ cells that mediate the adaptive immune response. While antibody-mediated immunity is mainly strain-specific and can prevent infection, $\mathrm{T}$ cells (especially $\mathrm{CD} 8^{+} \mathrm{T}$ cells) provide broadly cross-reactive cellular immunity against different influenza viruses and thus can ameliorate the severity of influenza disease [9-13]. Current vaccination strategies with 
inactivated influenza viruses induce strain-specific, B cell-based protective immunity directed against the viral hemagglutinin protein [14]. However, these vaccines offer little crossprotection against antigenic drift variants of seasonal IAVs and IBVs Therefore, the vaccine formulation needs to be updated annually to cover antigenically drifted IAV and IBV strains. Notably, current seasonal influenza vaccines do not protect against new and unanticipated influenza viruses, such as pandemic strains.

$\mathrm{T}$ cells recognize epitopes on conserved internal viral proteins and thus they confer broader protection across IAV subtypes $[9,15]$. Ideally, vaccination strategies that induce broadly cross-protective $\mathrm{T}$ cell responses across antigenic drift variant influenza viruses, and potentially against newly emerging zoonotic IAVs, are required to limit the disease burden of influenza epidemics and pandemics. Here, we summarize the current knowledge on the innate and adaptive $\mathrm{T}$ cell responses to influenza viruses and discuss how these responses can be exploited by vaccines to prevent or ameliorate severe influenza infections.

\section{Innate immunity as the first barrier against influenza viruses}

The innate immune response involves powerful antiviral activity mediated by interferon (IFN), which limits early viral spread and subsequently shapes the adaptive immune response by their cytokine secretion [16]. Innate immunity to influenza viruses also involves several innate $\mathrm{T}$ cell subsets such as mucosal-associated invariant (MAIT), natural killer (NKT) and $\gamma \delta$ T cells, which have been a focus of the recent studies.

\section{Mucosal-associated invariant T (MAIT) cells contribute to immunity against influenza viruses}

MAIT cells constitute up to $5 \%$ of the total $\mathrm{T}$ cell pool in humans and are characterized by the expression of a semi-invariant $\mathrm{T}$ cell receptor (TCR) $\mathrm{V} \alpha 7.2$ that recognizes bacterial-derived vitamin B2 derivatives presented by the MHC-like protein 1 (MR1) [17]. On activation, MAIT cells produce proinflammatory cytokines and upregulate cytotoxic granzymes and perforin [18]. Although MAIT cells are predominantly associated with control of bacterial infections, there is increasing evidence of their clinical importance in viral infections, autoimmune diseases and cancers [19-26]. With respect to human IAV infection, van Wilgenburg et al showed that the number of human MAIT cells in the peripheral blood of severely ill individuals was reduced by nearly half and they were highly activated, as shown by upregulation of granzyme B [26]. Furthermore, Loh et al showed that patients who died from severe H7N9 infection had $\sim 3-5$-fold fewer MAIT cells in the blood, compared to patients who recovered 
from severe H7N9 infection or were healthy [25]. These studies suggest a loss and/or efflux of MAIT cells from the blood to the site of infection during severe influenza disease. Further, both studies showed that the MAIT cell activation in influenza infection was MR1-TCR independent and was mediated by IL-18 [25,26], mainly produced by CD14 ${ }^{+}$monocytes [25]. Reduction in MAIT cell numbers during acute influenza infection could impair protective antibacterial immunity increasing the risk of bacterial co-infection, which would enhance disease severity and mortality [27].

\section{NKT cells modulate both innate and adaptive response mechanisms during influenza infection}

Natural killer $\mathrm{T}$ cells are innate-T lymphocytes restricted by the glycolipid $\alpha$ galactosylceramide $(\alpha \mathrm{GC})$ presented on MHC class I-like CD1d molecules. Like conventional T cells, they express $\alpha \beta$ TCRs as well as NK cell markers including CD3, CD56 (humans) or NK1.1 (mice). NKT cells constitute approximately $0.1-0.2 \%$ of the total $\mathrm{T}$ cell pool and are broadly classified into 2 groups: type I invariant NKT (iNKT) cells, expressing the invariant $\mathrm{V} \alpha 14-\mathrm{J} \alpha 18 \mathrm{TCR} \alpha$ chain paired with either V $\beta 2, \mathrm{~V} \beta 7$ or $\mathrm{V} \beta 8$ in mice and V $\alpha 24-\mathrm{J} \alpha 18 / \mathrm{V} \beta 11$ in humans, and type II diverse NKT cells, which display very diverse $\alpha \beta$ TCR gene pairings $[28,29]$. In animals, NKT cells can protect against viral infections and cancer $[28,30]$ by regulating innate and adaptive immune responses via rapid secretion of cytokines $[31,32]$, upregulation of CD40 and activation of dendritic cells [33].

In a mouse model of influenza infection, intraperitoneal (i.p.) administration of $\alpha \mathrm{GC}$ along with intranasal (i.n) administration of an influenza virus (H1N1/H3N2 recombinant) activates iNKT cells (without affecting the adaptive $\mathrm{T}$ cell responses), consequently reducing body weight loss and viral lung titres [34]. Conversely, CD1d-/- mice lacking the CD1d molecule (and therefore, lacking CD1d-stimulation of NKT cells), developed more severe disease following infection with a sublethal dose of influenza (PR8-H1N1) virus, as evidenced by lower body weight, higher lung viral titres, decreased IFN $\gamma$ production in the bronchoalveolar lavage (BAL) and impaired NK and T cell activity, as compared to wild type (WT) mice [35]. Similarly, Ja18-/- mice (lacking NKT cells expressing J $\alpha 18$ ) infected with the virulent influenza PR8-H1N1 virus displayed increased lung injury and mortality, associated with greater infiltration of Ly $6 \mathrm{C}^{\text {hi }} \mathrm{Ly} 6 \mathrm{G}^{-}$inflammatory monocytes in lungs, compared to J $\alpha 18$ /- mice receiving $\alpha \mathrm{GC}$-boosted iNKT cells. Moreover, $\alpha \mathrm{GC}$-boosted iNKT cells reduced MCP1 levels by lysing influenza-infected monocytes in a CD1d-dependent manner [36]. These 
findings were consistent with another study, in which a rapid reduction in body weight and $100 \%$ mortality by 11 days post-infection (d.p.i.) was observed in J 1 18-/- mice. The enhanced pathology in influenza-infected Ja18-/-mice was associated with a $\sim 4$-fold decrease in $\mathrm{D}^{\mathrm{b}} \mathrm{PA}_{224-233-s p e c i f i c ~ C D 8}{ }^{+} \mathrm{T}$ cells in lungs at 4 and 7 d.p.i. and differential accumulation and maturation of $\mathrm{CD} 103^{+}$dendritic cells (DCs) [37]. Moreover, the absence of iNKT cells led to suppression of IAV responses due to increased expression of the arginase and nitric oxide system and this was mitigated by adoptive transfer of iNKT cells that restored antiviral immunity in a CD1d- and CD40-dependent manner [38]. Furthermore, the use of $\alpha \mathrm{GC}$ as a vaccine adjuvant improved long-term survival of $\mathrm{CD}^{+}$cytotoxic $\mathrm{T}$ lymphocytes and provided heterologous protection in a mouse model of influenza infection [39]. Similarly, $\alpha \mathrm{GC}$ analogues, KBC-007 and KBC-009, administered with inactivated influenza A/PR/8/34 virus boosted humoral and cellular immune responses in mucosal and systemic compartments post immunization and induced protective immune responses when challenged with PR8 virus [40]. Intramuscular administration of inactivated A/California/04/2009 pandemic H1N1 virus with $\alpha \mathrm{GC}$ to piglets increased NKT-cell numbers, induced high titres of anti-HA mAbs and boosted IAV-specific $\mathrm{CD}^{+} \mathrm{T}$ cells post-vaccination. Virus challenge in piglets vaccinated with $\alpha \mathrm{GC} /$ inactivated virus resulted in reduced viral shedding in comparison to piglets vaccinated with whole inactive virus alone [41]. Intranasal immunization with inactivated influenza $\mathrm{A} / \mathrm{PR} / 8 / 34$ virus with $\alpha \mathrm{GC}$ in $\mathrm{BALB} / \mathrm{c}$ mice induced $\mathrm{IgG}$ and $\operatorname{IgA}$ antibodies lasting up to 3 months and boosted cellular immunity in comparison to mice immunized with inactivated PR8 virus alone [42].

Collectively, these animal studies demonstrate the role played by NKT cells in modulating innate and adaptive immune responses during IAV infection. $\alpha \mathrm{GC}$ as a vaccine adjuvant boosted NKT numbers and improved protection, further supporting the role of NKT cells in ensuring optimal influenza-specific $\mathrm{T}$ and $\mathrm{B}$ cell responses in the mucosal and systemic compartments. Despite the large number of animal studies investigating the role of NKT cells during influenza infection, there is a paucity of data supporting their protective role in human influenza, and this warrants further investigation.

\section{Anti-viral potential of $\gamma \delta$ T cells during influenza virus infection.}

$\gamma \delta \mathrm{T}$ cells (approximately $1-10 \%$ of peripheral blood $\mathrm{T}$ cells in humans) are important components of both innate and adaptive immunity, displaying a vast array of effector functions, making them attractive targets for therapeutic vaccines. $\gamma \delta \mathrm{T}$ cells are characterised by a diverse range of TCRs, with specific $\mathrm{V} \gamma-\mathrm{V} \delta$ pairings found across different anatomical sites. The 
antigen specificity of $\gamma \delta \mathrm{T}$ cells remains largely unclear. While butyrophilin (BTN) protein family molecules can regulate immunosurveillance of $\gamma \delta \mathrm{T}$ cells (reviewed in [43]), phosphoantigens (pAg, recognized via a mechanism involving BTN3A1), human MutS homologue 2 and F1-ATPase along with apolipoprotein can activate $\mathrm{V} \gamma 9 \mathrm{~V} \delta 2 \mathrm{~T}$ cells, while CD1d or MICA-lipid complexes and endothelial protein $\mathrm{C}$ receptor can stimulate non-V $\delta 2 \mathrm{~T}$ cells. $\gamma \delta \mathrm{T}$ cells can directly kill virally-infected, cancerous or stressed cells by secreting perforin, granzyme B and granulysin, and can promote inflammation and wound healing, and assist antigen presenting cells in generating optimal, antigen-specific $\mathrm{T}$ cell responses (reviewed in $[43,44]$ ). Murine studies of influenza infection showed that $15-30 \%$ of the lymphocytes in the BAL between 10-15 d.p.i were $\gamma \delta \mathrm{T}$ cells , compared to very few at 5-7 d.p.i This suggests that $\gamma \delta$ T cells may play a pivotal role in recovery from influenza infection [45]. Moreover, in a secondary influenza infection model, mice that were challenged with an $\mathrm{H} 1 \mathrm{~N} 1$ virus a month following $\mathrm{H} 3 \mathrm{~N} 2$ virus infection, $\gamma \delta$ T cells isolated from the BAL acquired an NK1.1 phenotype and displayed potent cytotoxic functions, as shown by killing of H3N2 virus-infected target cells in the presence of PHA [46.]. Moreover, $\gamma \delta \mathrm{T}$ cell hybridomas, derived from TCR $\beta$-/- mouse, cleared IAV and IBV infections efficiently via Hsp60 upregulation in infected cells and not by any viral proteins [47]. In humans, ex-vivo $\gamma \delta \mathrm{T}$ cells rapidly produced IFN $\gamma$ and upregulated CD25 and CD69 following IAV infection. The activation of $\gamma \delta$ T cells is dependent on the mevalonate pathway, as shown by a potent reduction in antiviral responses on addition of mevastatin, a mevalonate pathway inhibitor [48]. Furthermore, in vitro studies with human peripheral blood mononuclear cells (PBMC) showed that $\mathrm{pAg}$-activated $\gamma \delta \mathrm{T}$ cells were capable of killing macrophages and lung alveolar epithelial cells infected with both human (H1N1) and avian (H5N1) influenza viruses [49-52]. Moreover, pAg isopentenyl pyrophosphate (IPP)-expanded human $\mathrm{V} \gamma 9 \mathrm{~V} \delta 2 \mathrm{~T}$ cells displayed cytolytic activity (as measured by $\%$ target cell death), increased production of IFN $\gamma$ against pandemic H1N1 virus-infected monocyte-derived macrophages and expressed the inflammatory chemokine receptors CCR1, CCR5, and CXCR5 [50]. pAg-reactive V $\gamma 9 \mathrm{~V} \delta 2$ T subsets harbour a semi-invariant $\mathrm{V} \gamma 9$ pairing with diverse $\mathrm{V} \delta 2 \mathrm{TCRs}$ [53]. $\mathrm{V} \gamma 9 \mathrm{~V} \delta 2 \mathrm{~T}$ cells are innate in nature as they get stimulated prior to exposure with environmental antigens, as exemplified by their potent activation following pAg exposure by fetal blood-derived $\mathrm{V} \gamma 9 \mathrm{~V} \delta 2 \mathrm{~T}$ cells [54]Overall, these human studies implicate that the pAg-reactive $\mathrm{V} \gamma 9 \mathrm{~V} \delta 2 \mathrm{~T}$ subsets harbour innate-like activity towards influenza infection. These findings highlight the anti-viral potential of $\gamma \delta \mathrm{T}$ 
cells during influenza infection and suggest that enhancement of $\gamma \delta$ T cell responses might be beneficial in protection against influenza viruses.

\section{Adaptive $T$ cells are crucial for recovery and long-term protection from influenza infection}

Following the initial wave of innate immunity, the adaptive immune system becomes activated and plays an important role in viral clearance, host recovery and establishment of immunological memory. The adaptive immune system consists of humoral (virus-specific antibodies) and cellular (CD4 ${ }^{+}$and $\mathrm{CD} 8^{+} \mathrm{T}$ cells) components. Here, we highlight the cellular aspects of influenza-specific adaptive immunity and discuss how the current vaccine strategies target memory $\mathrm{T}$ cells.

\section{$\mathrm{CDB}^{+} \mathrm{T}$ cells confer cross-protection across different influenza subtypes}

Cytotoxic $\mathrm{CD}^{+} \mathrm{T}$ cells promote efficient elimination of the virus and subsequent host recovery, via the production of pro-inflammatory cytokines and direct killing of virus-infected cells $[55,56]$. Influenza-specific $\mathrm{CD}^{+} \mathrm{T}$ cells play a key role in broadly cross-reactive immunity to influenza viruses because they recognise 8-11 amino acid long peptide fragments derived from highly conserved internal viral proteins, presented in the context of MHC class-I molecules. $\mathrm{CD}^{+} \mathrm{T}$ cell-mediated cross-protection against different influenza subtypes has been well established in animal studies, including delayed virus clearance in mice lacking $\mathrm{CD}^{+} \mathrm{T}$ cells [55], generation of influenza virus escape mutants in influenza-infected transgenic mice expressing influenza-specific $\mathrm{CD}^{+} \mathrm{TCR}$ [57], or even more strikingly, in wild-type MHC-I-matched (but not MHC-I mismatched) mice during acute influenza infection [58]. When mice that have recovered from a primary influenza infection are re-infected with a heterologous IAV (a strain with different surface glycoproteins but the same internal proteins) that is resistant to neutralization by antibody induced by the primary infection, influenzaspecific $\mathrm{CD}^{+} \mathrm{T}$ cells are responsible for accelerated viral clearance and reduced disease burden [13,59-61]. Studies in guinea pigs also demonstrated that priming with the 2009 pandemic H1N1 virus confers protection against the 2013 avian H7N9 IAV [62]. Recently influenzaspecific tissue-resident memory $\left(\mathrm{T}_{\mathrm{RM}}\right) \mathrm{CD} 8^{+} \mathrm{T}$ cells in the upper respiratory tract of mice were shown to be important in mediating protection from pulmonary influenza virus infection [63]. The presence of protective $\mathrm{CD}^{+} \mathrm{T}_{\mathrm{RM}}$ populations in the nasal tissue implies that these cytotoxic effectors are in place to contribute to the early control of infection. Indeed, in mouse studies the establishment of $\mathrm{CD}^{+} \mathrm{T}_{\mathrm{RM}}$ cells in the upper respiratory tract reduced viral 
replication in the nose as early as day 3 and day 5 after intranasal challenge, in a CD8 ${ }^{+} \mathrm{T}$ celldependent manner [63].

$\mathrm{CD}^{+} \mathrm{T}$ cells are also associated with protection from disease during human IAV infection. In a seminal paper by Andrew McMichael and colleagues [9], healthy volunteers were experimentally infected with the influenza A/Munich/1/79 (H1N1) virus. Individuals with demonstrable influenza-specific $\mathrm{CD}^{+} \mathrm{T}$ cell responses cleared the virus more efficiently, irrespective of the presence of pre-existing antibodies [9]. Subsequently, a retrospective report showed that individuals previously infected with H1N1 IAV in the 1950s were less susceptible to the $1957 \mathrm{H} 2 \mathrm{~N} 2$ pandemic [10], further supporting the idea of heterosubtypic immunity that is presumed to be conferred by cellular immunity because antibodies elicited by H1N1 viruses do not protect against H2N2 IAV infection. The advent of the $2009 \mathrm{H} 1 \mathrm{~N} 1$ pandemic provided further opportunities to determine the role of $\mathrm{CD}^{+} \mathrm{T}$ cells in protection against IAV infection. Indeed, in a household cohort study in the UK, pre-existing IFN $\gamma$-producing $\mathrm{CD}^{+} \mathrm{T}$ cell responses were associated with lower disease severity [12]. Furthermore, the Flu Watch study, recruiting influenza-infected patients in England between 2006 and 2010, showed a positive correlation between pre-existing IAV-specific $\mathrm{CD} 8^{+} \mathrm{T}$ cells and symptomatic, PCR-confirmed IAV infection during 3 seasonal epidemics and the 2009 H1N1 pandemic [64]. These studies provide compelling evidence that cytotoxic $\mathrm{CD}^{+} \mathrm{T}$ cells can confer some level of protection during infection with human influenza viruses. Recently, our group has extended these observations to infection with the avian H7N9 IAV that emerged in China in 2013 in a study of longitudinal samples from hospitalized patients during the first wave of H7N9 infections in China [13]. Patients with most rapid recovery (discharged within 2-3 weeks after hospitalisation) had early and robust $\mathrm{H} 7 \mathrm{~N} 9$-specific $\mathrm{CD} 8^{+} \mathrm{T}$ cell responses, followed later by neutralising antibody responses. Conversely, patients who succumbed to infection had delayed and or minimal cytotoxic $\mathrm{CD}^{+} \mathrm{T}$ cell responses. Thus, recovery from severe $\mathrm{H} 7 \mathrm{~N} 9$ infection was associated with robust early $\mathrm{CD} 8^{+} \mathrm{T}$ cell responses.

Longevity and antigen-specificity of influenza-specific $\mathrm{CD} 8^{+} \mathrm{T}$ cells

The ability of $\mathrm{CD} 8^{+} \mathrm{T}$ cells to provide cross-strain protection against distinct influenza viruses makes them promising and attractive vaccine targets. However, one needs to also consider the longevity and breadth of the $\mathrm{CD} 8^{+} \mathrm{T}$ cell response. Indeed, influenza-specific $\mathrm{CD}^{+} \mathrm{T}$ cells were stable in the peripheral blood of healthy adults over a period of 13 years, showing that memory $\mathrm{CD} 8^{+} \mathrm{T}$ cells are long-lived [65]. The breadth of $\mathrm{CD} 8^{+} \mathrm{T}$ cell responses results from the high degree of conservation of immunogenic epitopes; recent human studies showed that 
$\mathrm{CD}^{+} \mathrm{T}$ cells can confer cross-reactivity across multiple IAVs [66-68], including H7N9 [69,70] and H5N1 [71,72] viruses, as well as the two lineages of IBV [73]. Our group has recently identified a set of universal and immunodominant $C D 8^{+} \mathrm{T}$ cell epitopes (HLA-A*02:01/M1 ${ }_{58-}$ 66, HLA-A*03:01/NP265-273, HLA-B*08:01/NP225-233, HLA-B*18:01/NP219-226, HLA$\mathrm{B} * 57: 01 / \mathrm{NP}_{199-207}$ and HLA-B*27:05/NP $\left.383-391\right)$, which are conserved across $100 \%$ of known human IAVs (from the 1918 pandemic to the 2013 H7N9 strain) [69]. These epitopes encompass various HLA molecules that are differentially prevalent across ethnicities, being particularly rare in the Alaskan and Australian Indigenous populations [74]. It is pertinent to note, that cross-reactivity may occur even when new variant epitopes emerge, depending on the amino acid substitution and/or position of the mutation and its impact on TCR recognition of the peptide/MHCI complex as well the individual's TCR repertoire of the cognate $\mathrm{CD} 8^{+} \mathrm{T}$ cell population. For instance, mutations in anchor residues can allow for escape variants, as it was the case with HLA-B*27:05/NP $383-391$, whereby mutations in position 2 (R384G) abrogated binding of the peptide to the MHCI molecule [75]. Furthermore, for the HLAB*07:02 or HLA-B*35:01 presented $\mathrm{NP}_{418-426}$ peptide, while the anchor residues are maintained, cross-reactivity depends on the position of the mutation in the peptide and the nature of the substitution $[68,76]$. Conversely, in the context of HLA-A*02:01/M1 $58-66$, for which sporadic mutations have arisen over the last century, the public $\alpha \beta$ TCR clonotype (TRBV19/TRAV27) is able to robustly cross-react with all the variants through induced-fit molecular mimicry, although in some instances with lower affinity [67]. These studies highlight the importance of the TCR repertoire in determining the breadth and protective capacity of the cytotoxic $\mathrm{CD} 8^{+} \mathrm{T}$ cell responses.

While $\mathrm{CD}^{+} \mathrm{T}$ cells are crucial in conferring protection, excessive $\mathrm{CD} 8^{+} \mathrm{T}$ cell responses can lead to immunopathology, as recently reviewed by Duan and Thomas [77]. However, the exact molecular and cellular pathways that lead to regulated and effective CD8 ${ }^{+}$ $\mathrm{T}$ cell responses versus exuberant and pathogenic responses are not entirely clear [78]. Thus, future research is needed to understand how protective memory can be established without immunopathology. It is also important to note that $\mathrm{CD}^{+} \mathrm{T}$ cells do not provide sterilizing immunity against infection but promote rapid host recovery and thereby provide protection from disease symptoms and death. This is why $\mathrm{CD}^{+} \mathrm{T}$ cells play a pivotal role in reducing disease severity and preventing fatal infections especially during an outbreak of a novel antigenically-shifted influenza strain, to which there is no pre-existing neutralizing immunity in the general population. 
Thus, it is evident that $\mathrm{CD}^{+} \mathrm{T}$ cells can confer broad protective immunity to antigenically drifted and shifted influenza viruses. The HLA genotype and the TCR repertoire are two key factors that need to be considered in the design of T cell-targeted vaccine strategies to provide wide population coverage, while limiting immune escape.

\section{New insights into the role of $\mathrm{CD}^{+} \mathrm{T}$ cells during influenza virus infection}

$\mathrm{CD}^{+} \mathrm{T}$ cells (T helper cells, Th cells) commonly recognise viral peptide fragments that are 1216 amino acids in length, presented on major histocompatibility complex class II (MHC-II) molecules. They play an important role in promoting optimal $\mathrm{CD} 8^{+} \mathrm{T}$ cell and B cell responses during influenza infection. Following activation in the draining lymph nodes during influenza infection, naïve $\mathrm{CD} 4^{+} \mathrm{T}$ cells differentiate into effector cells capable of producing cytokines such as IFN $\gamma$ and IL-2, and migrate to the lung. This is accompanied by the loss of the homing receptor CD62L, downregulation of CCR7 and upregulation of CD44 and CD49d, with transient expression of CCR5 [79]. CD4 ${ }^{+} \mathrm{T}$ cells, especially $\mathrm{T}$ follicular helper cells (Tfh) $[80,81]$, help B cells to generate antibodies by providing co-stimulatory signals. They are important for the priming and maintenance of $\mathrm{CD}^{+} \mathrm{T}$ cell responses to generate efficient memory $[82,83]$.

Circulating $\mathrm{T}$ follicular helper cells (cTfh; $\mathrm{CXR}^{+} \mathrm{PD} 1^{+} \mathrm{CD} 4^{+} \mathrm{T}$ cells) have recently been identified during influenza infection and vaccination [84] as a prominent $\mathrm{CD}^{+} \mathrm{T}$ cell population in peripheral blood on day 7 after vaccination [85]. These cTfh cells express the Th1 phenotype (CXCR3 $\left.{ }^{+} \mathrm{CCR} 6^{-}\right)$and upregulate markers of activation ICOS and PD-1. Importantly, cTfh cells can provide help in the form of cytokines and co-stimulation signals, to memory B cells for development into antibody-secreting cells (ASCs) in vitro [85]. As a result, the presence of cTfh cells correlates with the magnitude and quality of the antibody response and the development of ASCs following vaccination with trivalent inactivated vaccines (TIV) $[85,86]$. The ontogeny and specificity of cTfh cells and their relationship to memory Tfh reservoirs in lymphoid tissues remain unclear. Recently, clonotypic analysis of cTfh cells revealed the recruitment of recurrent clonotypes following vaccination in multiple years, strongly indicating that the cTfh population that appears following vaccination is memory-derived [87]. Further understanding of the specificity and function of circulating and non-circulating Tfh cells in humans and the role of these cells in influenza infection may inform the development of improved vaccines.

$\mathrm{CD}^{+} \mathrm{T}$ cells assist $\mathrm{CD} 8^{+} \mathrm{T}$ cells in becoming activated by licensing Ag-presenting DCs via the CD154 (CD40L)/CD40 signalling pathway [88,89]. However, CD4 ${ }^{+}$T cell-mediated 
help for primary activation of naïve $\mathrm{CD} 8^{+} \mathrm{T}$ cells appears to be pathogen-dependent, as it was redundant during influenza virus or LCMV infections [90]. Efficient primary $\mathrm{CD}^{+} \mathrm{T}$ cell responses could be established in the absence of $\mathrm{CD}^{+} \mathrm{T}$ cell help, as shown by in mice depleted of $\mathrm{CD}^{+} \mathrm{T}$ cells or in MHC-II knock out mice [91,92]. Nevertheless, co-stimulatory signalling via $\mathrm{CD} 28$ is needed for primary $\mathrm{CD}^{+} \mathrm{T}$ cell activation [93] and is required to sustain $\mathrm{CD} 8^{+} \mathrm{T}$ cell responses after activation during the effector phase [94]. Furthermore, virus-specific $\mathrm{CD}^{+}$ $\mathrm{T}$ cells have a beneficial impact on primary and secondary responses for themselves, as $\mathrm{CD} 4^{+}$ $\mathrm{T}$ cell licensing of dendritic cells results in enhanced proliferation and differentiation of the cells in influenza infected mice [95].

Regardless of whether $\mathrm{CD}^{+} \mathrm{T}$ cell help is required for primary influenza-specific $\mathrm{CD}^{+}$ $\mathrm{T}$ cell responses, they are beneficial for generation and recall of $\mathrm{CD} 8^{+} \mathrm{T}$ cell memory in terms of numbers of antigen-specific $\mathrm{CD} 8^{+} \mathrm{T}$ cells after the secondary influenza virus infection $[82,96]$. Furthermore, $\mathrm{CD}^{+} \mathrm{T}$ cell help is needed to localise tissue resident memory $\mathrm{CD} 8^{+} \mathrm{T}$ cells to epithelial cells in the lung, as influenza infection in mice lacking help led to less expression of the integrin CD103 and a dislocation of $\mathrm{T}_{\mathrm{RMs}}$ at 45 dpi [97]. CD4 ${ }^{+} \mathrm{T}$ cell help during influenza priming of $\mathrm{CD}^{+} \mathrm{T}$ cells led to greater production of Granzyme $\mathrm{B}(\mathrm{GzmB})$ in the $\mathrm{T}_{\mathrm{RMs}}$ after secondary challenge [97].

In addition to their helper function for B cell antibody class switching [98] and licensing of $\mathrm{DCs}$ for $\mathrm{CD}^{+} \mathrm{T}$ cell activation, $\mathrm{CD} 4^{+} \mathrm{T}$ cells can acquire cytotoxic functions $[99,100]$. Notably, acquisition of cytotoxic functions after influenza virus infection in mice was strongly tissue-dependent. Therefore, in adoptive transfer studies, cytotoxic $\mathrm{CD}^{+} \mathrm{T}$ cells expressing GzmB and Perforin could be found preferentially in mucosal tissue such as the lungs [101] of influenza (PR8-Ova) infected mice but less often in draining mediastinal lymph nodes and spleen at 7 dpi [101]. Furthermore, the route of administration of the virus appears to be important: intranasal infection of mice with PR8 IAV resulted in recruitment of the cytolytic $\mathrm{CD}^{+} \mathrm{T}$ cells in the lungs, while intramuscular administration led to diminished lung cytolytic $\mathrm{CD}^{+} \mathrm{T}$ cells and sterilizing immunity [102]. Thus, the route of the administration is an important consideration for future vaccine approaches designed to elicit a protective immune barrier at the site of infection.

Ex vivo analysis of influenza-specific $\mathrm{CD}^{+} \mathrm{T}$ cells has been recently facilitated by the development of HLA class II tetramers, generally characterised by lower TCR-binding avidity to peptide/MHCII compared to tetramer-specific $\mathrm{CD} 8^{+} \mathrm{T}$ cells. When cross-reactivity to four strains, including the pandemic H1N1 virus was analysed in humans, antigen-specific $\mathrm{CD}^{+}{ }^{+} \mathrm{T}$ cells were detected against several influenza viral proteins, including the haemagglutinin $(\mathrm{H} 1$ 
and H3), neuraminidase (N1 and N2), nucleoprotein (NP), and Matrix 1 (M1) $[15,72,103]$. Cross-reactivity of influenza-specific memory $\mathrm{CD} 4^{+} \mathrm{T}$ cells was also shown using overlapping peptides derived from influenza A/Vietnam/CL26/2005 (H5N1) and influenza A/New York/232/2004 (H3N2) in healthy volunteers from the United Kingdom and Vietnam. The viral $\mathrm{M} 1$ and NP proteins were the immunodominant targets of this $\mathrm{CD}^{+} \mathrm{T}$ cell cross-recognition [72]. Further research, is needed to understand how $\mathrm{CD}^{+} \mathrm{T}$ cell help leads to the generation of efficient $\mathrm{CD}^{+}$and $\mathrm{CD} 8^{+} \mathrm{T}$ cell memory.

\section{Vaccine strategies for induction of broadly cross-reactive adaptive $T$ cell responses.}

Currently, inactivated influenza vaccines (IIV) remain the predominant strategy for inducing protective immunity for upcoming epidemics. The IIV, either in a trivalent (H1N1, H3N2 and one IBV from either lineage) or quadrivalent (H1N1, H3N2 and two IBV strains, one from each lineage) formulation, is prepared annually based on recommendations by the WHO. Although IIV induces a B cell and antibody response in primed individuals, it is a weak inducer of $\mathrm{T}$ cell immunity, with the exception of $\mathrm{CD}^{+} \mathrm{T}$ cells.

Promising approaches for targeting $\mathrm{CD} 4^{+} \mathrm{T}$ cells by vaccination include the use of oilin-water adjuvants such as MF59® adjuvant [104]. Another approach is the live-attenuated influenza virus vaccine (LAIV), which in contrast to injectable IIV, are able generate longterm and virus-specific lung tissue resident memory $\mathrm{CD} 4^{+}$and $\mathrm{CD} 8^{+} \mathrm{T}$ cells in mice [105]. However, human studies on LAIV show minimal increases in $\mathrm{CD}^{+} \mathrm{T}$ cell responses after vaccination, as measured by IFN $\gamma$ production [106,107]. Nevertheless, it remains unclear whether the poor results observed in these human LAIV trials are due to the fact that $\mathrm{CD} 8^{+} \mathrm{T}$ cells are being assessed within the peripheral blood, while memory $\mathrm{T}$ cell responses generated after LAIV in mice are established at the site of infection [108].

Given the prominent role of $\mathrm{T}$ cells in inducing protective and universal immunity, novel $\mathrm{T}$ cell-mediated vaccination strategies are required to complement the induction of antibodies and memory B cells. One novel vaccine formulation is the modified vaccinia virus Ankara (MVA) expressing the influenza viral proteins NP and M1. The MVA-NP+M1 vaccine can induce increases in the number of influenza-specific, IFN $\gamma$-secreting $\mathrm{CD} 8^{+} \mathrm{T}$ cells in adults $(<0.5 \%$ on $\mathrm{d} 56$ over $\mathrm{d} 0, \mathrm{n}=8)$ [109]. Additionally, the number of tetramer ${ }^{+}$HLA$\mathrm{A}^{*} 02: 01 / \mathrm{M}_{58-66}-$ specific $\mathrm{CD} 8^{+} \mathrm{T}$ cells were shown to increase modestly and upregulate the effector molecules granzyme A and perforin [110]. Importantly, compared to unvaccinated controls, the MVA-NP+M1 vaccine provided modest protection from clinical symptoms upon intranasal challenge with influenza A/Wisconsin/67/2005 (H3N2) [111]. Other vaccine 
formulations have incorporated influenza peptides into their formulations, such as Flu-v [112,113] and FP-0.01 [113], or the Multimeric-001 vaccine, which consists of a protein encompassing 9 highly conserved peptides from the M1, NP and HA proteins [114]. Individuals vaccinated with Flu-v showed a modest increase in IFN $\gamma^{+} \mathrm{T}$ cell responses following in vitro stimulation with peptides [112,115], and these responses correlated with reduced viral titres following challenge with A/Wisconsin/67/2005 (H3N2). However, there was no correlation between IFN $\gamma^{+} \mathrm{T}$ cell responses and clinical symptoms. Consistently, there were no significant differences in viral shedding or symptom score between vaccinated and unvaccinated volunteers following experimental challenge [115]. The FP-0.01 and Multimeric001 vaccines only show small increases in T cell responses following restimulation of PBMCs from vaccinated individuals and have yet to be tested for the protective efficacy against experimental IAV challenge $[113,114]$. Table 1 shows an overview of recent trials that target innate and adaptive $T$ cells for influenza vaccination $[39-42,104,105,107,109,111-116]$.

Overall, there are currently no vaccines that induce robust and protective $\mathrm{CD} 8^{+} \mathrm{T}$ cell responses against influenza viruses. Novel vaccination strategies that can establish broadly cross-reactive and long-lived memory $\mathrm{CD}^{+} \mathrm{T}$ cells are needed in order to complement antibody responses in the prevention of seasonal influenza and newly emerging influenza viruses.

\section{Concluding remarks}

Published studies show clear evidence that both the adaptive ( $\mathrm{T}$ and B cells) and innate (MAIT cells, $\gamma \delta$ T cells and NKT cells) immune responses play important roles in controlling influenza virus infection. Thus, vaccination strategies that link innate and adaptive cellular immune responses would be attractive. Currently licensed vaccine strategies do not induce robust and protective $\mathrm{T}$ cell responses. The development of a vaccine that induces cross-protective cellular immunity against different influenza strains and subtypes, including IAVs with pandemic potential, would be an excellent achievement.

\section{Acknowledgements}

SS is a recipient of the Victoria India Doctoral Scholarship and Melbourne International Fee Remission Scholarship (MIFRS), University of Melbourne. MK and SN are supported by Melbourne International Research Scholarships (MIRS) and MIFRS. KK is supported by the NHMRC Program Grant (ID 1071916) and the NHMRC Senior Research Fellowship Level B. 
The WHO Collaborating Centre for Reference and Research on Influenza is supported by the Australian Government Department of Health.

Compliance with ethics guidelines

Simone Nüssing, Sneha Sant, Marios Koutsakos, Kanta Subbarao, Thi H.O. Nguyen and Katherine Kedzierska declare that they have no financial conflicts of interest. This is a review article and no human or animal studies, which would require approvals from ethics committees, were performed in this manuscript.

\section{References:}

1. Bouvier NM, Palese P: The biology of influenza viruses. Vaccine 2008, 4:D49-53.

2. Paules C, Subbarao K: Influenza. . Lancet 2017.

3. Shaw M, Palese P: Orthomyxoviridae: The viruses and their replication. In Fields Virology 6th edition. Edited by Knipe D, Howley P: Lippincott Williams \& Wilkins; 2013:1691-1740.

4. Koutsakos M, Nguyen TH, Barclay WS, Kedzierska K: Knowns and unknowns of influenza B viruses. Future Microbiol 2016, 11:119-135.

5. van de Sandt CE, Bodewes R, Rimmelzwaan GF, de Vries RD: Influenza B viruses: not to be discounted. Future Microbiol 2015, 10:1447-1465.

6. WHO: A manual for estimating disease burden associated with seasonal influenza. 2015.

7. WHO: Fact sheet, No. 211 (2009). URL www. who. int/mediacentre/factsheets/fs211/en/index. html 2010.

8. La Gruta NL, K K, Stambas J, Doherty PC: A question of self-preservation: immunopathology in influenza virus infection. Immunol Cell Biol 2007, 85:85-92.

9. McMichael AJ, Gotch FM, Noble GR, Beare PA: Cytotoxic T-cell immunity to influenza. New Eng J Med 1983, 309:13-17.

10. Epstein SL: Prior H1N1 influenza infection and susceptibility of Cleveland Family Study participants during the $\mathrm{H} 2 \mathrm{~N} 2$ pandemic of 1957: an experiment of nature. $J$ Infect Dis 2006, 193:49-53

11. Wilkinson TM, Li CK, Chui CS, Huang AK, Perkins M, Liebner JC, Lambkin-Williams R, Gilbert A, Oxford J, Nicholas B, et al.: Preexisting influenza-specific CD4+ T cells correlate with disease protection against influenza challenge in humans. Nat Med 2012, 18:274-280.

12. Sridhar S, Begom S, Bermingham A, Hoschler K, Adamson W, Carman W, Bean T, Barclay W, Deeks JJ, Lalvani A: Cellular immune correlates of protection against symptomatic pandemic influenza. Nat Med 2013, 19:1305-1312.

13. Wang Z, Wan Y, Qiu C, Quinones-Parra S, Zhu Z, Loh L, Tian D, Ren Y, Hu Y, Zhang X, et al.: Recovery from severe $\mathrm{H} 7 \mathrm{N9}$ disease is associated with diverse response mechanisms dominated by CD8(+) T cells. Nat Commun 2015, 6:6833.

14. Baumgarth N, Herman OC, Jager GC, Brown LE, Herzenberg LA, Chen J: B-1 and B-2 Cell-Derived Immunoglobulin M Antibodies Are Nonredundant Components of the Protective Response to Influenza Virus Infection. J Exp Med 2000, 192:271-280.

15. Assarsson E, Bui HH, Sidney J, Zhang Q, Glenn J, Oseroff C, Mbawuike IN, Alexander J, Newman MJ, Grey $\mathrm{H}$, et al.: Immunomic analysis of the repertoire of T-cell specificities for influenza A virus in humans. $J$ Virol 2008, 82:12241-12251. 
16. Randall RE, Goodbourn S: Interferons and viruses: an interplay between induction, signalling, antiviral responses and virus countermeasures. J Gen Virol 2008, 89:147.

17. Treiner E, Lantz O: CD1d- and MR1-restricted invariant $T$ cells: of mice and men. Curr Opin Immunol 2006, 18:519-526.

18. Howson LJ, Salio M, Cerundolo V: MR1-Restricted Mucosal-Associated Invariant T Cells and Their Activation during Infectious Diseases. Front Immunol 2015, 6:303.

19. Kawachi I, Maldonado J Fau - Strader C, Strader C Fau - Gilfillan S, Gilfillan S: MR1restricted $V$ alpha $19 \mathrm{i}$ mucosal-associated invariant $T$ cells are innate $T$ cells in the gut lamina propria that provide a rapid and diverse cytokine response. $J$ Immunol 2006, 176:1618-1627.

20. Napier RJ, Adams EJ, Gold MC, Lewinsohn DM: The Role of Mucosal Associated Invariant T Cells in Antimicrobial Immunity. Front Immunol 2015, 6:344.

21. Sakala IG, Kjer-Nielsen L, Eickhoff CS, Wang X, Blazevic A, Liu L, Fairlie DP, Rossjohn $\mathrm{J}$, McCluskey J, Fremont $\mathrm{DH}$, et al.: Functional Heterogeneity and Antimycobacterial Effects of Mouse Mucosal-Associated Invariant $T$ Cells Specific for Riboflavin Metabolites. J Immunol 2015, 195:587-601.

22. Bianchini E, De Biasi S, Simone AM, Ferraro D, Sola P, Cossarizza A, Pinti M: Invariant natural killer $T$ cells and mucosal-associated invariant $T$ cells in multiple sclerosis. Immunol Lett 2017, 183:1-7.

23. Gracey E, Qaiyum Z, Almaghlouth I, Lawson D, Karki S, Avvaru N, Zhang Z, Yao Y, Ranganathan V, Baglaenko $Y$, et al.: IL-7 primes IL-17 in mucosal-associated invariant $T$ (MAIT) cells, which contribute to the Th17-axis in ankylosing spondylitis. Ann Rheum Dis 2016, 75:2124-2132.

24. Wang JJ, Macardle C, Weedon H, Beroukas D, Banovic T: Mucosal-associated invariant $T$ cells are reduced and functionally immature in the peripheral blood of primary Sjogren's syndrome patients. Eur J Immunol 2016, 46:2444-2453.

25. Loh L, Wang Z, Sant S, Koutsakos M, Jegaskanda S, Corbett AJ, Liu L, Fairlie DP, Crowe $\mathrm{J}$, Rossjohn $\mathrm{J}$, et al.: Human mucosal-associated invariant $\mathbf{T}$ cells contribute to antiviral influenza immunity via IL-18-dependent activation. Proc Natl Acad Sci U S A 2016, 113:10133-10138.

26. van Wilgenburg BA-OhooX, Scherwitzl I, Hutchinson ECA-Ohoo, Leng T, Kurioka A, Kulicke C, de Lara C, Cole S, Vasanawathana S, Limpitikul W, et al.: MAIT cells are activated during human viral infections. Nat Commun 2016:2041-1723 (Electronic).

27. McCullers JA: The co-pathogenesis of influenza viruses with bacteria in the lung. Nat Rev Micro 2014, 12:252-262.

28. Godfrey DI, Uldrich AP, McCluskey J, Rossjohn J, Moody DB: The burgeoning family of unconventional T cells. Nat Commun 2015, 16:1114-1123.

29. Rossjohn J, Pellicci Dg Fau - Patel O, Patel O Fau - Gapin L, Gapin L Fau - Godfrey DI, Godfrey DI: Recognition of CD1d-restricted antigens by natural killer $\mathbf{T}$ cells. Nat Rev Immunol 2012, 12:845-857.

30. Tessmer MS, Fatima A Fau - Paget C, Paget C Fau - Trottein F, Trottein F Fau - Brossay L, Brossay L: NKT cell immune responses to viral infection. Expert Opin Ther Targets 2009, 13:153-162.

31. Crowe NY, Uldrich AP, Kyparissoudis K, Hammond KJL, Hayakawa Y, Sidobre S, Keating R, Kronenberg M, Smyth MJ, Godfrey DI: Glycolipid Antigen Drives Rapid Expansion and Sustained Cytokine Production by NK T Cells. J Immunol 2003, 171:4020-4027.

32. Coquet JM, S. C, Kyparissoudis K, McNab FW, Pitt LA, McKenzie BS, Berzins SP, Smyth MJ, Godfrey DI: Diverse cytokine production by NKT cell subsets and 
identification of an IL-17-producing CD4-NK1.1- NKT cell population. Proc Natl Acad Sci U S A 2008, 105:11287-11292.

33. Vincent MS, Leslie DS, Gumperz JE, Xiong X, Grant EP, Brenner MB: CD1-dependent dendritic cell instruction. Nat Immunol 2002, 3:1163-1168.

34. Ho LP, L D, Luhn K, Teoh D, Clelland C, McMichael AJ: Activation of invariant NKT cells enhances the innate immune response and improves the disease course in influenza A virus infection. Eur J Immunol 2008, 38.

35. Ishikawa H, K. T, Kutsukake E, Fukui T, Sasaki H, Hata A, Noda S, Matsumoto T: IFNgamma production downstream of NKT cell activation in mice infected with influenza virus enhances the cytolytic activities of both NK cells and viral antigenspecific CD8+ T cells. Virology 2010, 407:325-332.

36. Kok WL, L. D, Benam K, Cole S, Clelland C, McMichael AJ, Ho LP: Pivotal Advance: Invariant NKT cells reduce accumulation of inflammatory monocytes in the lungs and decrease immune-pathology during severe influenza A virus infection. $J$ Leukoc Biol 2012, 91:357-368.

37. Paget C, Ivanov S, Fontaine J, Blanc F, Pichavant M, Renneson J, Bialecki E, Pothlichet J, Vendeville C, Barba-Speath G, et al.: Potential Role of Invariant NKT Cells in the Control of Pulmonary Inflammation and CD8\&It;sup\&gt;+\&It;/sup\&gt; T Cell Response during Acute Influenza A Virus H3N2 Pneumonia. J Immunol 2011, 186:5590.

38. De Santo C, Salio M, Masri SH, Lee LY-H, Dong T, Speak AO, Porubsky S, Booth S, Veerapen N, Besra GS, et al.: Invariant NKT cells reduce the immunosuppressive activity of influenza $A$ virus-induced myeloid-derived suppressor cells in mice and humans. J Clin Invest 2008, 118:4036-4048.

39. Guillonneau C, Mintern JD, Hubert F-X, Hurt AC, Besra GS, Porcelli S, Barr IG, Doherty PC, Godfrey DI, Turner SJ: Combined NKT cell activation and influenza virus vaccination boosts memory CTL generation and protective immunity. Proc Natl Acad Sci U S A 2009, 106:3330-3335.

40. Lee YS, K.A L, Lee J-Y, Kang M-H, Song YC, Baek DJ, Kim S, Kang CY: An alphaGalCer analogue with branched acyl chain enhances protective immune responses in a nasal influenza vaccine. Vaccine 2011, 29:417-425.

41. Artiaga BL, Yang G, Hackmann TJ, Liu Q, Richt JA, Salek-Ardakani S, Castleman WL, Lednicky JA, Driver JP: $\boldsymbol{\alpha}$-Galactosylceramide protects swine against influenza infection when administered as a vaccine adjuvant. Sci Rep 2016, 6:23593.

42. Youn HJ, S.Y. K, Lee KA, Ko H-J, Lee Y-S, Fujihashi K, Boyaka PN, Kim S-H, Horimoto $\mathrm{T}$, Kweon $\mathrm{M}-\mathrm{N}$, et al.: A single intranasal immunization with inactivated influenza virus and alpha-galactosylceramide induces long-term protective immunity without redirecting antigen to the central nervous system. Vaccine 2007, 25:51895198.

43. Kabelitz D, Lettau M, Janssen O: Immunosurveillance by human gammadelta $\mathbf{T}$ lymphocytes: the emerging role of butyrophilins. LID - F1000 Faculty Rev-782 [pii] LID - 10.12688/f1000research.11057.1 [doi]. f1000research 2017.

44. Bonneville M, Scotet E: Human Vgamma9Vdelta2 $\mathbf{T}$ cells: promising new leads for immunotherapy of infections and tumors. Curr Opin Immunol 2006, 18:539-546.

45. Carding SR, Allan W, Kyes S, Hayday A, Bottomly K, Doherty PC: Late dominance of the inflammatory process in murine influenza by gamma/delta + T cells. $J$ Exp Med 1990, 172:1225-1231.

46. Eichelberger M, Doherty PC: Gamma delta $\mathbf{T}$ cells from influenza-infected mice develop a natural killer cell phenotype following culture. Cell Immunol 1994, 159:94-102. 
47. Wallace M, Malkovsky M, Carding SR: Gamma/delta T lymphocytes in viral infections. J Leukoc Biol 1995, 58:277-283.

48. Jameson JM, Cruz J, Costanzo A, Terajima M, Ennis FA: A role for the mevalonate pathway in the induction of subtype cross-reactive immunity to influenza A virus by human gammadelta T lymphocytes. Cell Immunol 2010, 264:71-77.

49. Qin G, Mao H, Zheng J, Sia SF, Liu Y, Chan PL, Lam KT, Peiris JS, Lau YL, Tu W: Phosphoantigen-expanded human gammadelta $T$ cells display potent cytotoxicity against monocyte-derived macrophages infected with human and avian influenza viruses. J Infect Dis 2009, 200:858-865.

50. Qin G, Liu Y, Zheng J, Ng IH, Xiang Z, Lam KT, Mao H, Li H, Peiris JS, Lau YL, et al.: Type 1 responses of human Vgamma9Vdelta2 T cells to influenza A viruses. $J$ Virol 2011, 85:10109-10116.

51. Tu W, Zheng J, Liu Y, Sia SF, Liu M, Qin G, Ng IH, Xiang Z, Lam KT, Peiris JS, et al.: The aminobisphosphonate pamidronate controls influenza pathogenesis by expanding a gammadelta $\mathbf{T}$ cell population in humanized mice. $J$ Exp Med 2011, 208:1511-1522.

52. Li H, Xiang Z, Feng T, Li J, Liu Y, Fan Y, Lu Q, Yin Z, Yu M, Shen C, et al.: Human Vgamma9Vdelta2-T cells efficiently kill influenza virus-infected lung alveolar epithelial cells. Cell Mol Immunol 2013, 10:159-164.

53. Davey MS, Willcox CR, Joyce SP, Ladell K, Kasatskaya SA, McLaren JE, Hunter S, Salim $\mathrm{M}$, Mohammed F, Price DA, et al.: Clonal selection in the human V $\delta 1 \mathrm{~T}$ cell repertoire indicates $\gamma \delta \boldsymbol{\delta}$ TCR-dependent adaptive immune surveillance. Nature Communications 2017, 8:14760.

54. Dimova T, Brouwer M, Gosselin F, Tassignon J, Leo O, Donner C, Marchant A, Vermijlen D: Effector Vgamma9Vdelta2 $\mathbf{T}$ cells dominate the human fetal gammadelta $\mathbf{T}$ cell repertoire.

55. Bender BS, Croghan T, Zhang L, Small PAJ: Transgenic mice lacking class I major histocompatibility complex- restricted $T$ cells have delayed viral clearance and increased mortality after influenza virus challenge. $J$ Exp Med 1992, 175:11431145.

56. Doherty PC, J. TD, Tripp RA: Establishment and persistence of virus-specific CD4+ and CD8+ T cell memory. Immunol Rev 1996, 150:23-44.

57. Price GE, Ou R, Jiang H, Huang L, Moskophidis D: Viral Escape by Selection of Cytotoxic T Cell-Resistant Variants in Influenza a Virus Pneumonia. $J$ Exp Med 2000, 191:1853-1868.

58. Valkenburg SA, S. Q-P, Gras S, Komadina N, McVernon J, Wang Z, Halim H, Iannello P, Cole $\mathrm{C}$, Laurie $\mathrm{K}$, et al.: Acute emergence and reversion of influenza $A$ virus quasispecies within CD8+ T cell antigenic peptides. Nat Commun 2013:2041-1723 (Electronic).

59. Duan S, Meliopoulos VA, McClaren JL, Guo XZ, Sanders CJ, Smallwood HS, Webby RJ, Schultz-Cherry SL, Doherty PC, Thomas PG: Diverse heterologous primary infections radically alter immunodominance hierarchies and clinical outcomes following H7N9 influenza challenge in mice. PLoS Pathog 2015, 11:e1004642.

60. Valkenburg SA, Gras S, Guillonneau C, La Gruta NL, Thomas PG, Purcell AW, Rossjohn J, Doherty PC, Turner SJ, Kedzierska K: Protective efficacy of cross-reactive CD8+ $T$ cells recognising mutant viral epitopes depends on peptide-MHC-I structural interactions and T cell activation threshold. PLoS Pathog 2010, 6:e1001039.

61. Valkenburg SA, Venturi V, Dang TH, Bird NL, Doherty PC, Turner SJ, Davenport MP, Kedzierska K: Early priming minimizes the age-related immune compromise of CD8(+) T cell diversity and function. PLoS Pathog 2012, 8:e1002544. 
62. Wiersma LC, Vogelzang-van Trierum SE, Kreijtz JH, van Amerongen G, van Run P, Ladwig M, Banneke S, Schaefer H, Fouchier RA, Kuiken T, et al.: Heterosubtypic immunity to $\mathrm{H} 7 \mathrm{N9}$ influenza virus in isogenic guinea pigs after infection with pandemic H1N1 virus. Vaccine 2015.

63. Pizzolla A, Wang Z, Groom JR, Kedzierska K, Brooks AG, Reading PC, Wakim LM: Nasal-associated lymphoid tissues (NALTs) support the recall but not priming of influenza virus-specific cytotoxic T cells. Proc Natl Acad Sci U S A 2017, 114:52255230.

64. Hayward AC, Wang L, Goonetilleke N, Fragaszy EB, Bermingham A, Copas A, Dukes O, Millett ER, Nazareth I, Nguyen-Van-Tam JS, et al.: Natural T Cell-mediated Protection against Seasonal and Pandemic Influenza. Results of the Flu Watch Cohort Study. Am J Respir Crit Care Med 2015, 191:1422-1431.

65. van de Sandt CE, Hillaire ML, Geelhoed-Mieras MM, Osterhaus AD, Fouchier RA, Rimmelzwaan GF: Human Influenza A Virus-Specific CD8+ T-Cell Response Is Long-lived. J Infect Dis 2015, 212:81-85.

66. Hillaire ML, Vogelzang-van Trierum SE, Kreijtz JH, de Mutsert G, Fouchier RA, Osterhaus AD, Rimmelzwaan GF: Human T-cells directed to seasonal influenza A virus cross-react with 2009 pandemic influenza A (H1N1) and swine-origin triplereassortant H3N2 influenza viruses. $J$ Gen Virol 2013, 94:583-592.

67. Valkenburg SA, Josephs TM, Clemens EB, Grant EJ, Nguyen TH, Wang G, Price DA, Miller A, Tong SY, Thomas PG, et al.: Molecular basis for universal HLA-A*0201restricted CD8+ T-cell immunity against influenza viruses. Proc Natl Acad Sci U S A 2016, 113:4440-4445.

68. Gras S, Kedzierski L, Valkenburg SA, Laurie K, Liu YC, Denholm JT, Richards MJ, Rimmelzwaan GF, Kelso A, Doherty PC, et al.: Cross-reactive CD8+ T-cell immunity between the pandemic H1N1-2009 and H1N1-1918 influenza A viruses. Proc Natl Acad Sci U S A 2010, 107:12599-12604.

69. Quinones-Parra S, Grant E, Loh L, Nguyen TH, Campbell KA, Tong SY, Miller A, Doherty PC, Vijaykrishna D, Rossjohn J, et al.: Preexisting CD8+ T-cell immunity to the H7N9 influenza A virus varies across ethnicities. Proc Natl Acad Sci U S A 2014, 111:1049-1054.

70. van de Sandt CE, Kreijtz JH, de Mutsert G, Geelhoed-Mieras MM, Hillaire ML, Vogelzang-van Trierum SE, Osterhaus AD, Fouchier RA, Rimmelzwaan GF: Human cytotoxic $T$ lymphocytes directed to seasonal influenza A viruses cross-react with the newly emerging H7N9 virus. $J$ Virol 2014, 88:1684-1693.

71. Kreijtz JH, de Mutsert G, van Baalen CA, Fouchier RA, Osterhaus AD, Rimmelzwaan GF: Cross-recognition of avian H5N1 influenza virus by human cytotoxic Tlymphocyte populations directed to human influenza A virus. J Virol 2008, 82:5161-5166.

72. Lee LY, Ha do LA, Simmons C, de Jong MD, Chau NV, Schumacher R, Peng YC, McMichael AJ, Farrar JJ, Smith GL, et al.: Memory T cells established by seasonal human influenza $A$ infection cross-react with avian influenza A (H5N1) in healthy individuals. J Clin Invest 2008, 118:3478-3490.

73. van de Sandt CE, Dou Y, Vogelzang-van Trierum SE, Westgeest KB, Pronk MR, Osterhaus AD, Fouchier RA, Rimmelzwaan GF, Hillaire ML: Influenza B virus-specific CD8+ T-lymphocytes strongly cross-react with viruses of the opposing influenza $B$ lineage. J Gen Virol 2015, 96:2061-2073.

74. Marsh SGE, Parham P, Barber LD: The HLA factsbook. San Diego: Academic Press; 2000.

75. Berkhoff EGM, Boon ACM, Nieuwkoop NJ, Fouchier RAM, Sintnicolaas K, Osterhaus ADME, Rimmelzwaan GF: A Mutation in the HLA-B*2705-Restricted NP383-391 
Epitope Affects the Human Influenza A Virus-Specific Cytotoxic T-Lymphocyte Response In Vitro. J Virol 2004, 78:5216-5222.

76. Boon ACM, de Mutsert G, Graus YMF, Fouchier RAM, Sintnicolaas K, Osterhaus ADME, Rimmelzwaan GF: Sequence Variation in a Newly Identified HLA-B35-Restricted Epitope in the Influenza A Virus Nucleoprotein Associated with Escape from Cytotoxic T Lymphocytes. J Virol 2002, 76:2567-2572.

77. Duan S, Thomas PG: Balancing Immune Protection and Immune Pathology by CD8(+) T-Cell Responses to Influenza Infection. Front Immunol 2016, 7:25.

78. Hillaire MLB, Rimmelzwaan GF, Kreijtz J: Clearance of influenza virus infections by $\mathbf{T}$ cells: risk of collateral damage? Curr Opin Virol 2013, 3:430-437.

79. Román E, Miller E, Harmsen A, Wiley J, von Andrian UH, Huston G, Swain SL: CD4 Effector T Cell Subsets in the Response to Influenza. $J$ Exp Med 2002, 196:957-968.

80. Goodnow CC, Vinuesa CG, Randall KL, Mackay F, Brink R: Control systems and decision making for antibody production. Nat Immunol 2010, 11:681-688.

81. Ma CS, Deenick EK, Batten M, Tangye SG: The origins, function, and regulation of $\mathbf{T}$ follicular helper cells. $J$ Exp Med 2012, 209:1241-1253.

82. Belz GT, Wodarz D, Diaz G, Nowak MA, Doherty PC: Compromised Influenza VirusSpecific CD8+-T-Cell Memory in CD4+-T-Cell-Deficient Mice. J Virol 2002, 76:12388-12393.

83. Shedlock DJ, Shen H: Requirement for CD4 T cell help in generating functional CD8 T cell memory. Science 2003, 300:337-339.

84. Morita R, Schmitt N, Bentebibel SE, Ranganathan R, Bourdery L, Zurawski G, Foucat E, Dullaers M, Oh S, Sabzghabaei N, et al.: Human blood CXCR5(+)CD4(+) T cells are counterparts of $\mathbf{T}$ follicular cells and contain specific subsets that differentially support antibody secretion. Immunity 2011, 34:108-121.

85. Bentebibel SE, Lopez S, Obermoser G, Schmitt N, Mueller C, Harrod C, Flano E, Mejias A, Albrecht RA, Blankenship D, et al.: Induction of ICOS+CXCR3+CXCR5+ TH cells correlates with antibody responses to influenza vaccination. Sci Transl Med 2013, 5:176ra132.

86. Bentebibel SE, Khurana S, Schmitt N, Kurup P, Mueller C, Obermoser G, Palucka AK, Albrecht RA, Garcia-Sastre A, Golding H, et al.: ICOS(+)PD-1(+)CXCR3(+) T follicular helper cells contribute to the generation of high-avidity antibodies following influenza vaccination. Sci Rep 2016.

87. Herati RS, Muselman A, Vella L, Bengsch B, Parkhouse K, Del Alcazar D, Kotzin J, Doyle $S A$, Tebas $P$, Hensley $S E$, et al.: Successive annual influenza vaccination induces a recurrent oligoclonotypic memory response in circulating $\mathbf{T}$ follicular helper cells. Sci Immunol 2017, 2:eaag2152.

88. Bennett SRM, Carbone FR, Karamalis F, Flavell RA, Miller JFAP, Heath WR: Help for cytotoxic-T-cell responses is mediated by CD40 signalling. Nature 1998, 393:478480.

89. Schoenberger SP, Toes RE, van der Voort EI, Offringa R, Melief CJ: T-cell help for cytotoxic T lymphocytes is mediated by CD40-CD40L interactions. Nature 1998, 393:480-483.

90. Johnson S, Zhan Y, Sutherland RM, Mount AM, Bedoui S, Brady JL, Carrington EM, Brown LE, Belz GT, Heath WR, et al.: Selected Toll-like receptor ligands and viruses promote helper-independent cytotoxic $T$ cell priming by upregulating CD40L on dendritic cells. Immunity 2009, 30:218-227.

91. Tripp RA, Sarawar Sr Fau - Doherty PC, Doherty PC: Characteristics of the influenza virus-specific $\mathrm{CD8}+\mathrm{T}$ cell response in mice homozygous for disruption of the $\mathbf{H}$ 2lAb gene. J Immunol 1995, 155:2955-2959. 
92. Ahmed R, Butler LD, Bhatti L: T4+ T helper cell function in vivo: differential requirement for induction of antiviral cytotoxic $\mathbf{T}$-cell and antibody responses. $J$ Virol 1988, 62:2102-2106.

93. Seah SG, Carrington EM, Ng WC, Belz GT, Brady JL, Sutherland RM, Hancock MS, La Gruta NL, Brown LE, Turner SJ, et al.: Unlike CD4+ T-cell help, CD28 costimulation is necessary for effective primary CD8+ T-cell influenza-specific immunity. Eur $J$ Immunol 2012, 42:1744-1754.

94. Dolfi DV, Duttagupta PA, Boesteanu AC, Mueller YM, Oliai CH, Borowski AB, Katsikis PD: Dendritic cells and CD28 costimulation are required to sustain virus-specific CD8+ T cell responses during the effector phase in vivo. J Immunol 2011, 186:45994608.

95. Olson MR, Seah SG, Cullen J, Greyer M, Edenborough K, Doherty PC, Bedoui S, Lew AM, Turner SJ: Helping themselves: optimal virus-specific CD4 $\mathbf{T}$ cell responses require help via CD4 T cell licensing of dendritic cells. $J$ Immunol 2014, 193:54205433.

96. Sun JC, Bevan MJ: Defective CD8 T Cell Memory Following Acute Infection Without CD4 T Cell Help. Science 2003, 300:339-342.

97. Laidlaw BJ, Zhang N, Marshall HD, Staron MM, Guan T, Hu Y, Cauley LS, Craft J, Kaech SM: CD4+ $T$ cell help guides formation of $\mathrm{CD103+} \mathrm{lung-resident} \mathrm{memory} \mathrm{CD8+}$ T cells during influenza viral infection. Immunity 2014, 41:633-645.

98. McKinstry KK, Strutt TM, Kuang Y, Brown DM, Sell S, Dutton RW, Swain SL: Memory CD4+ $T$ cells protect against influenza through multiple synergizing mechanisms. J Clin Invest 2012, 122:2847-2856.

99. Marshall NB, Swain SL: Cytotoxic CD4 T cells in antiviral immunity. $J$ Biomed Biotechnol 2011, 2011:954602.

100. Juno JA, van Bockel D, Kent SJ, Kelleher AD, Zaunders JJ, Munier CM: Cytotoxic CD4 T Cells-Friend or Foe during Viral Infection? Front Immunol 2017, 8:19.

101. Hua L, Yao S, Pham D, Jiang L, Wright J, Sawant D, Dent AL, Braciale TJ, Kaplan MH, Sun J: Cytokine-dependent induction of CD4+ $\mathbf{T}$ cells with cytotoxic potential during influenza virus infection. J Virol 2013, 87:11884-11893.

102. Dutta A, Huang CT, Lin CY, Chen TC, Lin YC, Chang CS, He YC: Sterilizing immunity to influenza virus infection requires local antigen-specific $T$ cell response in the lungs. Sci Rep 2016, 6:32973.

103. Richards KA, Topham D, Chaves FA, Sant AJ: Cutting Edge: CD4 T Cells Generated from Encounter with Seasonal Influenza Viruses and Vaccines Have Broad Protein Specificity and Can Directly Recognize Naturally Generated Epitopes Derived from the Live Pandemic H1N1 Virus. J Immunol 2010, 185:4998-5002.

104. Galli G, Medini D, Borgogni E, Zedda L, Bardelli M, Malzone C, Nuti S, Tavarini S, Sammicheli C, Hilbert AK, et al.: Adjuvanted H5N1 vaccine induces early CD4+ T cell response that predicts long-term persistence of protective antibody levels. Proc Natl Acad Sci U S A 2009, 106:3877-3882.

105. Zens KD, Chen JK, Farber DL: Vaccine-generated lung tissue-resident memory $\mathbf{T}$ cells provide heterosubtypic protection to influenza infection. JCI Insight 2016, 1:e85832.

106. He XS, Holmes TH, Zhang C, Mahmood K, Kemble GW, Lewis DB, Dekker CL, Greenberg HB, Arvin AM: Cellular immune responses in children and adults receiving inactivated or live attenuated influenza vaccines. J Virol 2006, 80:1175611766.

107. Peng Y, Wang B, Talaat K, Karron R, Powell TJ, Zeng H, Dong D, Luke CJ, McMichael A, Subbarao K, et al.: Boosted Influenza-Specific T Cell Responses after H5N1 
Pandemic Live Attenuated Influenza Virus Vaccination. Front Immunol 2015, 6:287.

108. Wang Z, Chua BY, Ramos JV, Parra SM, Fairmaid E, Brown LE, Jackson DC, Kedzierska $\mathrm{K}$ : Establishment of functional influenza virus-specific $\mathbf{C D 8}(+) \mathrm{T}$ cell memory pools after intramuscular immunization. Vaccine 2015, 33:5148-5154.

109. Berthoud TK, Hamill M, Lillie PJ, Hwenda L, Collins KA, Ewer KJ, Milicic A, Poyntz HC, Lambe T, Fletcher HA, et al.: Potent CD8+ T-cell immunogenicity in humans of a novel heterosubtypic influenza A vaccine, MVA-NP+M1. Clin Infect Dis 2011, 52:1-7.

110. Powell TJ, Peng Y, Berthoud TK, Blais ME, Lillie PJ, Hill AV, Rowland-Jones SL, McMichael AJ, Gilbert SC, Dong T: Examination of influenza specific $\mathbf{T}$ cell responses after influenza virus challenge in individuals vaccinated with MVANP+M1 vaccine. PLoS One 2013, 8:e62778.

111. Lillie PJ, Berthoud TK, Powell TJ, Lambe T, Mullarkey C, Spencer AJ, Hamill M, Peng Y, Blais ME, Duncan CJ, et al.: Preliminary assessment of the efficacy of a T-cellbased influenza vaccine, MVA-NP+M1, in humans. Clin Infect Dis 2012, 55:19-25.

112. Pleguezuelos O, Robinson S, Stoloff GA, Caparros-Wanderley W: Synthetic Influenza vaccine (FLU-v) stimulates cell mediated immunity in a double-blind, randomised, placebo-controlled Phase I trial. Vaccine 2012, 30:4655-4660.

113. Francis JN, Bunce CJ, Horlock C, Watson JM, Warrington SJ, Georges B, Brown CB: A novel peptide-based pan-influenza A vaccine: a double blind, randomised clinical trial of immunogenicity and safety. Vaccine 2015, 33:396-402.

114. Atsmon J, Kate-Ilovitz E, Shaikevich D, Singer Y, Volokhov I, Haim KY, Ben-Yedidia $\mathrm{T}$ : Safety and immunogenicity of multimeric-001--a novel universal influenza vaccine. J Clin Immunol 2012, 32:595-603.

115. Pleguezuelos O, Robinson S, Fernandez A, Stoloff GA, Mann A, Gilbert A, Balaratnam G, Wilkinson T, Lambkin-Williams R, Oxford J, et al.: A Synthetic Influenza Virus Vaccine Induces a Cellular Immune Response That Correlates with Reduction in Symptomatology and Virus Shedding in a Randomized Phase Ib Live-Virus Challenge in Humans. Clin Vaccine Immunol 2015, 22:828-835.

116. Kopecky-Bromberg SA, Fraser KA, Pica N, Carnero E, Moran TM, Franck RW, Tsuji M, Palese P: Alpha-C-galactosylceramide as an adjuvant for a live attenuated influenza virus vaccine. Vaccine 2009, 27:3766-3774. 
Table 1. Novel vaccine strategies targeting $T$ cells

\begin{tabular}{|c|c|c|c|c|c|}
\hline Host & $\begin{array}{l}\text { Immunisation } \\
\text { type }\end{array}$ & $\begin{array}{l}\text { Administration } \\
\text { route }\end{array}$ & Viral challenge & Findings & Reference \\
\hline \multicolumn{6}{|l|}{ NKT cells } \\
\hline $\begin{array}{l}\mathrm{C} 57 \mathrm{BL} / 6 \mathrm{~J} \\
\text { mice }\end{array}$ & $\begin{array}{l}\alpha \mathrm{GC} \text { adjuvant }+ \text { iIAV PR8 } \\
(\mathrm{H} 1 \mathrm{~N} 1)\end{array}$ & subcutaneous & $\mathrm{HK} \times 31(\mathrm{H} 3 \mathrm{~N} 2)$ & $\begin{array}{l}\text { Faster viral clearance; } \\
\text { Improved secondary responses } \\
\text { and long term survival of } \mathrm{CD} 8^{+} \mathrm{T} \\
\text { cells. }\end{array}$ & $\begin{array}{l}\text { Guillonneau } \\
\text { (2009) [39] }\end{array}$ \\
\hline $\begin{array}{l}\mathrm{BALB} / \mathrm{C} \\
\text { mice }\end{array}$ & $\begin{array}{ll}\alpha \mathrm{GC} \text { analogue } & \mathrm{KBC}-007 \\
\mathrm{KBC}-009+ & \text { formalin- } \\
\text { inactivated PR8 } & \end{array}$ & intranasal & PR8 & $\begin{array}{l}\text { Significantly higher } \mathrm{Ab} \text { titers } 4 \\
\text { wks after immunization compared } \\
\text { to PR8 alone with higher } \\
\text { neutralizing activity; } \\
\text { Rescue from otherwise lethal PR } 8 \\
\text { challenge in vaccine }+ \text { adjuvant } \\
\text { treated mice. }\end{array}$ & $\begin{array}{ll}\text { Lee } & (2011) \\
{[40]} & \end{array}$ \\
\hline pigs & $\begin{array}{l}\text { UV-inactivated H1N1 } \\
\text { A/California/04/2009 } \\
(\text { kCA04) SI virus }+\alpha G C\end{array}$ & intramuscular & CA04 & $\begin{array}{l}\text { Increased NKT-cell numbers, } \\
\text { high titres of anti-HA } \mathrm{Abs} \text { and } \\
\text { boosted IAV-specific } \mathrm{CD} 8^{+} \mathrm{T} \\
\text { cells, reduced viral shedding. }\end{array}$ & $\begin{array}{l}\text { Artiaga } \\
(2016)[41]\end{array}$ \\
\hline $\begin{array}{l}\mathrm{BALB} / \mathrm{c} \\
\text { mice }\end{array}$ & $\begin{array}{l}\text { Formalin-inactivated PR8 } \\
+\alpha \mathrm{GC}\end{array}$ & intranasal & PR8 & $\begin{array}{l}\text { IgG and } \operatorname{IgA} \text { antibodies lasting up } \\
\text { to } 3 \text { months; reduced viral titers; } \\
\text { improved survival from lethal } \\
\text { challenge. }\end{array}$ & $\begin{array}{l}\text { Youn (2007) } \\
{[42]}\end{array}$ \\
\hline $\begin{array}{l}\mathrm{BALB} / \mathrm{c} \\
\text { mice }\end{array}$ & $\begin{array}{l}\text { LAIV (PR8) (rNS1 1-73)) } \\
+\alpha \mathrm{GC} \text { derivate (alpha-C- } \\
\text { GalCer) }\end{array}$ & intranasal & PR8 & $\begin{array}{l}\text { Reduced morbidity and mortality; } \\
\text { increased amount of IA Ab (IgG, } \\
\text { IgG1, and IgG2a); increased IFN } \gamma \\
\text { secreting CD8 }{ }^{+} \text {T cells. }\end{array}$ & $\begin{array}{l}\text { Kopecky- } \\
\text { Bromberg } \\
(2009)[113]\end{array}$ \\
\hline \multicolumn{6}{|l|}{ T cells } \\
\hline Human & $\begin{array}{l}\text { Monovalent } \mathrm{H} 5 \mathrm{N1} \\
(\mathrm{A} / \text { Vietnam/1194/2004) } \\
\text { subunit vaccine }+ \text { MF59® } \\
\text { adjuvant }\end{array}$ & intramuscular & $\begin{array}{l}\text { In vitro peptide } \\
\text { stimulation: } \\
\text { H5 } \\
\text { A/Vietnam/1194/2 } \\
004 \quad \text { (clade 1), } \\
\text { A/Indonesia/5/05 } \\
\text { (clade 2.1), and } \\
\text { A/duck/Singapore/ } \\
97 \text { (clade } 0-\text { like) }\end{array}$ & $\begin{array}{l}\text { High titers of neutralizing; long } \\
\text { lasting } \mathrm{Ab}(>6 \text { months), increased } \\
\text { pool of memory B cells and H5- } \\
\mathrm{CD} 4^{+} \mathrm{T} \text { cells; in vitro responses to } \\
\text { non-conserved regions of } \mathrm{H} 5 \text {. }\end{array}$ & $\begin{array}{ll}\text { Galli } & (2009) \\
{[101]} & \end{array}$ \\
\hline $\begin{array}{l}\mathrm{C} 57 \mathrm{BL} / 6 \\
\text { mice }\end{array}$ & $\begin{array}{l}\text { LAIV (FluMist) } \\
\text { (Quadrivalent } \\
\text { (A/California/7/2009 } \\
\text { (H1N1)pdm09, } \\
\text { A/Texas/50/2012 (H3N2), } \\
\text { B/Massachusetts/2/2012, } \\
\text { or B/Brisbane/60/2008) } \\
\text { (2014-2015) and } \\
\text { Quadrivalent } \\
\text { (A/California/7/2009 } \\
\text { (H1N1)pdm09, A/ } \\
\text { Switzerland/9715293/201 } \\
3 \text { (H3N2), } \\
\text { B/Phuket/3073/2013, and } \\
\text { B/Brisbane/60/2008) } \\
\text { (2015-2016) }\end{array}$ & intranasal & $\begin{array}{l}\text { PR8 or X31 or } \\
\text { heterosubtypic } \\
\text { challenge PR8 or } \\
\text { X31 }\end{array}$ & $\begin{array}{l}\text { localized } \mathrm{CD}^{+} \text {and virus specific } \\
\mathrm{CD} 8^{+} \mathrm{T} \text { cells in the lung; long- } \\
\text { term responses ( } 45 \text { weeks) and } \\
\text { tissue resident memory } \mathrm{T} \text { cells; } \\
\text { heterosubtypic protection. }\end{array}$ & $\begin{array}{ll}\text { Zens } & (2016) \\
{[102]} & \end{array}$ \\
\hline Human & H5N1 pLAIV VN2004 & intranasal & $\begin{array}{l}\text { In vitro peptide } \\
\text { stimulation: } \\
\text { H5N1; } \\
\text { nonconserved HA } \\
\text { proteins of relevant } \\
\text { seasonal H1N1 and } \\
\text { H3N2 viruses }\end{array}$ & $\begin{array}{l}\text { Increased IFN } \gamma \text { responses of } \\
\text { PBMCs to conserved internal } \\
\text { proteins } \mathrm{M} \text { and NP; temporary } \\
\text { increase of influenza specific } \\
\mathrm{CD} 8^{+} \mathrm{T} \text { cells. }\end{array}$ & $\begin{array}{ll}\text { Peng } & (2015) \\
{[104]}\end{array}$ \\
\hline Human & $\begin{array}{l}\text { Modified Vaccinia Virus } \\
\text { Ankara (MVA)-NP+M1 } \\
\text { (A/Panama/2007/99) }\end{array}$ & intradermal & $\begin{array}{l}\text { In vitro peptide } \\
\text { stimulation } \\
\mathrm{NP}+\mathrm{M} 1-\end{array}$ & $\begin{array}{l}\text { Slight increase of IFN } \gamma \text { producing } \\
\text { PBMCs and CD8 } 8^{+} \text {T cells } \\
\text { responses to NP and M1. }\end{array}$ & $\begin{array}{l}\text { Berthoud } \\
\text { (2011) [106] }\end{array}$ \\
\hline Human & Ankara (MVA)-NP+M1 & intramuscular & $\begin{array}{l}\text { A/Wisconsin/67/20 } \\
05 \text { (H3N2) }\end{array}$ & $\begin{array}{l}\text { Reduced influenza symptoms } \\
\text { after infection. }\end{array}$ & $\begin{array}{l}\text { Lillie (2012) } \\
{[108]}\end{array}$ \\
\hline Human & $\begin{array}{l}\text { Synthetic poly-peptide } \\
\text { vaccine } \\
\text { FLU-v w/wo adjuvant } \\
\text { ISA-51 }\end{array}$ & subcutaneous & $\begin{array}{l}\text { In vitro stimulation } \\
\text { with FLU-v }\end{array}$ & $\begin{array}{l}\text { Increased IFN } \gamma \text { response in } \\
\text { PBMCs after vaccination with } \\
\text { adjuvant. }\end{array}$ & $\begin{array}{l}\text { Pleguezuelos } \\
(2012)[109]\end{array}$ \\
\hline Human & $\begin{array}{l}\text { Synthetic poly-peptide } \\
\text { vaccine } \\
\text { FLU-v + adjuvant ISA-51 }\end{array}$ & & $\begin{array}{l}\text { A/Wisconsin/67/20 } \\
05 \text { (H3N2) }\end{array}$ & $\begin{array}{l}\text { Flu-v specific IFN } \gamma \text { responses of } \\
\text { CD } 8^{+} \mathrm{T} \text { cells } 19 \text { days after } \\
\text { vaccination; no significant } \\
\text { differences in total viral shedding } \\
\text { or total symptom score between } \\
\text { placebo and FLU-v vaccinated }\end{array}$ & $\begin{array}{l}\text { Pleguezuelos } \\
(2015)[112]\end{array}$ \\
\hline
\end{tabular}




\begin{tabular}{|c|c|c|c|c|c|}
\hline Human & $\begin{array}{l}\text { Synthetic peptide FP-0.01 } \\
\text { (FlunisynTM) }\end{array}$ & intramuscular & 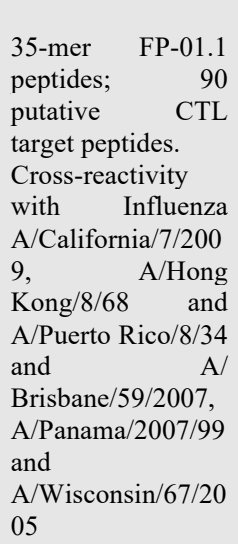 & $\begin{array}{l}\text { groups a.i. } \\
\text { More IFN } \gamma \text { production in } \mathrm{CD}^{+} \\
\text {and CD8 }{ }^{+} \mathrm{T} \text { cells after } \\
\text { vaccination and restimulation } \\
\text { with FP-01.1; higher GzmB } \\
\text { production of PBMCs after } \\
\text { vaccination in a cross-protective } \\
\text { manner (A549 cell infection with } \\
\text { H1N1 strains or H3N2 strains). }\end{array}$ & $\begin{array}{l}\text { Francis } \\
(2015)[110]\end{array}$ \\
\hline Human & $\begin{array}{lr}\text { Peptide } & \text { vaccine } \\
\text { Multimeric-001 } & \text { w/wo } \\
\text { adjuvant (Montanide ISA } \\
51 \mathrm{VG} \text { ) }\end{array}$ & intramuscular & $\begin{array}{l}\text { MDCK cells } \\
\text { infected with } \\
\text { H1N1, H3N2, and } \\
\text { influenza B }\end{array}$ & $\begin{array}{l}\text { Increase in } \mathrm{IgG} \text { titers against } \\
\text { multimeric- } 001 \text { protein after } 2^{\text {nd }} \\
\text { vaccination in adjuvanted } \\
\text { vaccine. }\end{array}$ & $\begin{array}{l}\text { Atsmon } \\
(2012)[111]\end{array}$ \\
\hline
\end{tabular}

Ab, antibody; a.i., after infection; IA, influenza A; PBMCs, peripheral blood mononuclear cell; wks, weeks; w/wo, with/without. 


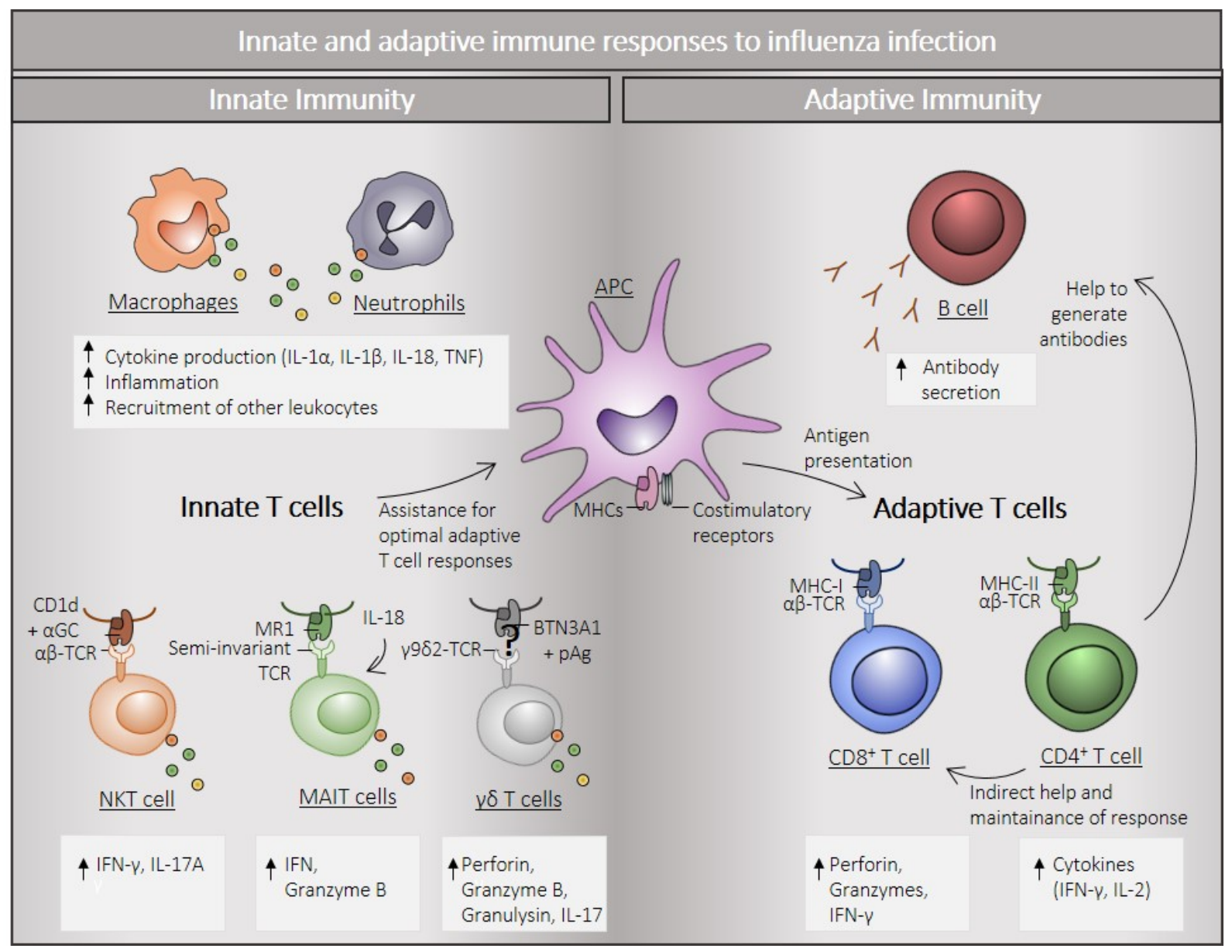

Figure 1. Activation of the innate and adaptive arms of the immune system during influenza virus infection. Influenza virus infection leads to activation of innate cells, such as macrophages and neutrophils, to secrete pro-inflammatory cytokines resulting in the recruitment of other leukocytes. Innate $\mathrm{T}$ cells play an important role in dampening the effects of influenza infection by the secretion of cytokines and cytotoxic molecules. The exact mechanisms of how these innate $\mathrm{T}$ cells are activated (TCR-dependent or indirectly by soluble factors) during influenza virus infection remain controversial. In addition, innate $\mathrm{T}$ cells provide important signal molecules to enhance APC activity, which in turn present influenza antigens to $\mathrm{CD} 8^{+} \mathrm{T}$ cells and $\mathrm{CD} 4^{+} \mathrm{T}$ cells for effective viral clearance. $\mathrm{CD} 4^{+} \mathrm{T}$ cells can also provide help to $\mathrm{CD} 8^{+} \mathrm{T}$ cells and antibody-producing $\mathrm{B}$ cells to enhance the antiviral response. 